\title{
The Level of Lead (Pb) among Students in Qatar Schools and its Relationship to Academic Achievement and Violent Behavior
}

\author{
Alkhatib $\mathrm{AJ}^{1 *}$ and Alalawneh $\mathrm{MAA}^{2}$ \\ ${ }^{1}$ Department of Legal Medicine, Jordan University of Science \& Technology, Jordan \\ ${ }^{2}$ Ministry of Higher Education, Qatar
}

*Corresponding author: Ahed J Alkhatib, Department of Legal Medicine, Toxicology and Forensic Medicine, International Mariinskaya Academy, department of medicine and critical care, department of philosophy, Academician secretary of department of Sociology, Jordan University of Science \& Technology, Jordan, Tel: 00962795905145; Email: ajalkhatib@just.edu.jo

\section{Research Article}

Volume 5 Issue 3

Received Date: June 12, 2020

Published Date: July 06, 2020

DOI: $10.23880 /$ act- 16000187

\section{Abstract}

Introduction: Lead $(\mathrm{Pb})$ has no any known biological or physiological function in the body. Its accumulation has been associated with various damaging effects, particularly in the nervous system.

Study objectives: to measure the lead concentration of two groups of school students in Qatar: a group of students with good academic achievement and a group of students with low academic achievement; and to explore different patterns of behavior related to perceptions of violence between student groups and to check if this can be linked to lead exposure.

Methods and subjects: a case control study was conducted. Study sample included 40 schoolchildren students assigned into two groups: group I ( $\mathrm{N}=20)$ includes students with good academic achievement, and group II (N=20) includes students with bad academic achievements. Urine samples were taken from all students and tested for lead concentration by atomic spectrometer.

Study findings: lead concentration in-group I $(0.00015 \pm 0.00007 \mathrm{pg} / \mathrm{ml})$ was significantly lower than that in-group II $(0.0114 \pm 0.008 \mathrm{pg} / \mathrm{ml}),(\mathrm{p}=0.008)$. The modes of behaviors in-group II pointed to rioting modes that involve insulting teachers, colleagues and school properties.

Conclusions: schoolchildren with bad academic achievements tend to have high levels of lead, which is expected to influence their modes of behaviors.

Keywords: Lead; Exposure; Schoolchildren; Academic Achievement; Behaviors

\section{Introduction}

Lead $(\mathrm{Pb})$ is a common substance in our environment. It has no known physiological roles in biological systems [1,2]. When exposed to it, it is absorbed inside the body and kept for a long time in the blood and bone. Lead exposure is linked to multiple damages to the various systems in the body, such as the nervous system, which leads to poor academic achievement and growing trends of violence, especially school violence [3]. Lead exposure has also been associated with mortality (principally because of cardiovascular diseases), impeded renal function, hypertension, fertility troubles, and bad pregnancy results. The accumulation of $\mathrm{Pb}$ in human organs is undesirable as it impacts metabolic pathways [4].

The amassing of $\mathrm{Pb}$ in people occurs through ingestion of food, drinking water, soil, and the inward breath of 
environmental $\mathrm{Pb}$ dust [5-7]. Lead may reach into the body because of the erosion of drinking water pipes covered with lead, and may likewise bring about medical issues through learning and social issue, for example, mental alterations [8]. At the point when exposed to high dosages of lead, harmful episodes are likely to occur in the brain, the red blood cells, and the kidney [9]. Lead in drinking water may originate from tainting at the source, yet it can likewise be available in faucet water as a aftereffect of its disintegration from normal sources; rather, its quality is fundamentally from family plumbing frameworks containing lead in pipes, joints, fittings, or the administration associations with homes [4].

\section{Study Problem}

Violence in educational circles is considered one of the problems affecting society because of the extremist behaviors that are hostile to civil society. Various social studies are trying to find justifications and explanations related to this phenomenon, but they have not found radical solutions to this phenomenon within the social system, which created a void in the research that needs to be rethought in a new way. In this study, we assumed the presence of environmental and biological factors that lead to violence.

\section{Study Hypotheses}

- Exposure to some heavy elements as a lead element has an important correlation with poor academic achievement compared to the non-exposed group at the alpha level of significance less or equal to 0.05 .

- Exposure to the lead lement has an important correlation with violent behaviors such as abuse of teachers and school-specific properties compared to the non-exposed group of lead element at the alpha level of significance less or equal to 0.05 .

\section{Study Questions}

The study answers the following questions:

- Do students with low academic achievement have high levels of lead compared with students with high academic achievement?

- Did exposure to lead, lead to violent and riotous behavior among Qatari school students?

\section{The Importance of this Study}

The importance of the study lies in the fact that it addresses one of the most important problems facing our region, namely violence and extremism. Extremism leads to violence like attacking others and property. This study has taken a different approach related to researching the phenomenon of violence environmentally and biologically through studying the impact of the lead component on violent behaviors and academic achievement, and thus this study may be the first of its kind in the region where the research team did not find similar studies, which opens the door to a new type of research has It contributes to identifying and treating individuals who are vulnerable to violence.

\section{Study Objectives}

- To measure the lead concentration of two groups of school students in Qatar: a group of students with good academic achievement and a group of students with low academic achievement.

- To explore different patterns of behavior related to perceptions of violence between student groups and to check if this can be linked to lead exposure.

\section{Methods and subjects}

\section{Study design}

A case control study between two groups of students with good academic achievement and low academic achievement was conducted.

\section{Study Community}

School students in Qatar.

\section{Study Sample}

The study included 40 students divided into twenty students with a good academic achievement and 20 students with a low academic achievement.

\section{Study Data Collection}

Approval of the study was taken from the Research Ethics Committee of the Ministry of Education and Higher Education in Qatar prior to start collecting urine samples and filling study questionnaire.

\section{Study Instrument}

A special questionnaire was designed for this study by reviewing the international literature on violent behavior. It involved paragraphs specific to student opinions in the school and administration environment and the motivations for violent behavior. The participation of students was optional and with the consent of the parents, who signed in writing the participation of their children in the study. 


\section{Lead Element Measurement}

The lead element was measured in urine samples for all students participating in the study by an atomic spectrometer. The result was given in units of $\mathrm{pg} / \mathrm{ml}$ of urine.

\section{Statistical Analysis}

Data was analyzed using SPSS version 21. Descriptive analytical models were used to describe and represent data. The difference in means between study groups was determined by independent $\mathrm{T}$ test. Significance was considered at $\alpha \leq 0.05$.

\section{Results}

\section{Concentration of Lead}

The students were divided into two groups:

- The first group: the group of diligent students, and the average lead concentration was $0.00015 \mathrm{pg} / \mathrm{ml}$.

- The second group: the group of riot students and their average lead concentration was $0.0114 \mathrm{pg} / \mathrm{ml}$.

- The difference in mean between the two averages was statistically significant $(\mathrm{p}=0.008)$ (Table 1$)$.
Accordingly, it can be said that exposure to lead has an active role in the lack of academic achievement and violent behavior.

\begin{tabular}{|c|c|c|c|}
\hline Variable & M & SD & P value \\
\hline $\begin{array}{c}\text { Lead -good academic } \\
\text { achievement }\end{array}$ & 0.00015 & 0.00007 & \\
\cline { 1 - 3 } $\begin{array}{c}\text { Lead- bad academic } \\
\text { achievement }\end{array}$ & 0.0114 & 0.008 & \\
\hline
\end{tabular}

Table 1: Identification of $P$ value.

\section{The Opinions of Hard-Working Students (Good Academic Achievements)}

As seen in Table 2, the opinions of students with good academic achievements were summarized. The data showed that there were several patterns of good behaviors in the class such as: liking teaching method (100\%), the desire to attend class $(100 \%)$, not to insult teacher $(100 \%)$, not to quarrel with teacher, or colleagues (100\%). Not to riot $(100 \%)$. On the other hand, school liking was reported by $85 \%$ of students, and not to write on the school walls was reported by $90 \%$ of the same school children.

\begin{tabular}{|c|c|c|}
\hline Variable & Frequency (N) & Percentage (\%) \\
\hline Like the teaching method & 20 & $100 \%$ \\
\hline Would like to attend classes & 20 & $100 \%$ \\
\hline School liking & 17 & $85 \%$ \\
\hline Do not insult the teacher & 20 & $100 \%$ \\
\hline Do not quarrel with colleagues & 20 & $100 \%$ \\
\hline Do not quarrel with teachers & 20 & $100 \%$ \\
\hline Do not write on the walls & 18 & $90 \%$ \\
\hline Do not riot & 20 & $100 \%$ \\
\hline
\end{tabular}

Table 2: Patterns of Reported Behaviors of Schoolchildren (with A Good Academic Achievement).

The Opinions of the Rioting Students (with Bad Academic Achievements)

As shown in Table 3, rioting students (with bad academic achievements) expressed their views as: $75 \%$ of violence is due to distress and discomfort, $45 \%$ of these students perceived that violence and quarreling are the most prevalent behaviors, $100 \%$ reported that their relationships with their colleagues are good, 90\% expressed their views about the relationships with school as good and accepted, $100 \%$ expressed their opinions about being ignored by school management in making decisions, 35\% expressed their opinions as crowding is annoying. All rioting students in this study think that lessons are not a matter, and they think that teachers are not treating them well. Also, all rioting students think that teaching methods are not good, and they are not interested in attending classes, and they do not like schools. Insulting teachers was reported by $65 \%$ of rioting students, $95 \%$ of students reported quarreling with colleagues and teachers. All rioting students reported writing on walls. Rioting actions were reported by $95 \%$ students. From these findings, the effect of lead exposure on academic achievement, violent perceptions and behaviors is evident. 


\begin{tabular}{|c|c|c|}
\hline Behavior & Frequency $(\mathrm{N})$ & Percentage $(100 \%)$ \\
\hline \multicolumn{3}{|l|}{ Violence is due to } \\
\hline - $\quad$ Distress and discomfort & 15 & $75 \%$ \\
\hline - Lack of activities & 3 & $15 \%$ \\
\hline - Secondary conditions & 2 & $10 \%$ \\
\hline Violence and quarreling are the most prevalent behaviors & 9 & $45 \%$ \\
\hline Good relationships with colleagues as good & 20 & $100 \%$ \\
\hline Relationship with the school as acceptable and good & 18 & $90 \%$ \\
\hline Not considered by school management in making decisions & 20 & $100 \%$ \\
\hline Crowding is annoying & 7 & $35 \%$ \\
\hline Lessons are not a matter & 20 & $100 \%$ \\
\hline Teachers are not treating student well & 20 & $100 \%$ \\
\hline Teaching methods are not good & 20 & $100 \%$ \\
\hline Not interested in attending classes & 20 & $100 \%$ \\
\hline They don't like school & 20 & $100 \%$ \\
\hline Insulting teacher & 13 & $65 \%$ \\
\hline Quarreling with colleagues & 19 & $95 \%$ \\
\hline Quarreling with teachers & 19 & $95 \%$ \\
\hline Writing on walls & 20 & $100 \%$ \\
\hline Rioting actions & 19 & $95 \%$ \\
\hline
\end{tabular}

Table 3: Patterns of Reported Behaviors of Schoolchildren (with A Bad Academic Achievement).

\section{Discussion}

Exposure to lead element has been associated with physiological alteration through induction of damaging effects on various biological systems and organs including nervous system [1,3,7]. The results of this study showed that school children with bad academic achievement had higher level of lead $(\mathrm{Pb})(0.0114 \pm 0.008 \mathrm{pg} / \mathrm{ml})$ compared with the lead level of diligent students $(0.00015 \pm 0.0007 \mathrm{pg} /$ $\mathrm{ml})$. These findings clearly revealed the importance of lead exposure on mental activities. However, lead exposure is an attractive topic and we previously studied it and got similar findings. We studied the impacts of lead exposure on a sample of jailed arrested persons and found that the lead level among jailed persons to be higher than the control group [10]. We also studied the impact of lead exposure on mental retardation and found that patients with mental retardation had relatively higher levels of lead compared with the control group [11].

The results of this study showed that students who had bad academic achievements and higher lead levels also expressed rioting behaviors and tendency towards insulting teachers and colleagues. These results did not agree with other previous studies that showed lead levels were not correlated with student's behaviors [12]. However, the results of this study are consistent with other studies that showed lead exposure was correlated with defects in neurobehavioural and cognitive development in young children [13-15].

\section{Conclusions and Recommendations}

- The results indicated that the effect of exposure to lead is significant on students 'behavior and achievement, so the study recommends that all students to be tested for lead element and to adopt special educational policies for students with high blood lead levels.

- To test the possibility of exposure to other elements such as mercury, chromium and nickel.

- To conduct environmental studies to ensure that the environment is compatible with global health standards.

- To search for the appropriate approaches to reduce the lead concentration in students who have high blood lead levels.

\section{References}

1. NourEddine D, Miloud S, Abdelkader A (2005) Effect of lead exposure on dopaminergic transmission in the rat brain. Toxicology 207(3): 363-368. 
2. Gautam K, Pradhan S, Thuppil V, Pyakurel D, Shrestha A (2017) Blood lead level among school children in an industrial city of Nepal. Journal of Pathology of Nepal 7(1): 1091-1094.

3. Wright JP, Dietrich KN, Ris MD, Hornug RW, Wessel SD, et al. (2008) Association of prenatal and childhoodblood lead concentrations with criminal arrests in early adulthood. PLoS Medicine 5(5): 101.

4. WHO (2017) Guidelines for Drinking-Water Quality, Fourth Edition Incorporating the First Addendum. World Health Organization, Geneva, Switzerland.

5. Haider T, Haider M, Wruss $\mathrm{W}$, Sommer R, Kundi $\mathrm{M}$ (2002) Lead in drinking water of Vienna in comparison to other European countries and accordance with recent guidelines. International Journal of Hygiene and Environmental Health 205(5): 399-403.

6. Ahmed K, Ayana G, Engidawork E (2008) Lead exposure study among workers in lead acid battery repair units of transport service enterprises, Addis Ababa, Ethiopia: a cross sectional study. Journal of Occupational Medicine and Toxicology 3: 30.

7. Winther M, Slento E (2010) Heavy Metal Emissions for Danish Road Transport. Technical report no. 780. National Environmental Research Institute, Aarhus University, Denmark.

8. Bakır B, Babayigit MA, Tekbas OF, Ogur R, Kilic A, et al. (2015) Assessment of drinking water quality in public primary schools in a metropolitan area in Ankara, Turkey. International Journal of Health Sciences and
Research 5(4): 257-266.

9. USEPA (2018) 3Ts for Reducing Lead in Drinking Water in Schools and Child Care Facilities. United Stated Environmental Protection Agency, Washington, DC, USA.

10. Alkhatib AJ, Alta'any HM, Abdelal QM (2014) Lead exposure and possible association with violent crimes: a field study in two Jordanian prisons. European scientific journal 10(30): 1-8.

11. Boran AM, Al-Bashir NA, Al-Khatib AJ, T Qattan IT, Alanazi SA, et al. (2013) Investigating the relationship between mental retardation and lead intoxication. European Scientific Journal 9(6).

12. Maheswari BU, Vijayaraghavan R, Venkatesh T, Flora SJS (2015) Blood lead level and its impact on behavioural problems and intelligence among school children living near lead based industries. Wulfenia journal 22(1): 360374.

13. Ahamed M, Verma S, Kumar A, Siddiqui MK (2005) Environmental exposure to lead and its correlation with biochemical indices in children. Sci Total Environ 346(13): 48-45.

14. Liu J, Xu X, Wu K, Piao Z, Huang J, et al. (2011) Association between lead exposure from electronic waste recycling and child temperament alterations. Neurotoxicology 32(4): 458-464.

15. Liu J, Li L, Wang Y, Yan C, Liu X (2013) Impact of low blood lead concentrations on IQ and school performance in Chinese children. PLoS One 8(5). 